\title{
EDUCATIONAL WEB RESOURCES AS AN ESSENTIAL PART OF THE ENGLISH LEARNING PROCESS
}

\author{
RECURSOS EDUCACIONAIS ONLINE COMO PARTE ESSENCIAL DO PROCESSO \\ DE APRENDIZAGEM DA LÍNGUA INGLESA
}

\section{LOS RECURSOS EDUCATIVOS WEB COMO PARTE ESENCIAL DEL PROCESO DE APRENDIZAJE DEL IDIOMA INGLÉS}

\author{
Shi DANDAN ${ }^{1}$ \\ Zulfiia Kh. FAZLYEVA ${ }^{2}$ \\ Nadezhda O. SAMARKINA ${ }^{3}$ \\ Charles CARLSON ${ }^{4}$
}

\begin{abstract}
The article discusses the use of educational web resources in the process of learning English. The authors present different web resources to teach English which have proved to be an effective source in second language acquisition. Web resources help to improve the foreign language perception, to study grammar rules and correct pronunciation, to get acquainted to the culture of the target language and to heighten the interest of learning a foreign language. The advantage of using web resources lies behind the didactic principle of visibility. Visual representation of material proves to be the most important tool to better perceive information and to overall motivate children to stay focused on the task, while creating a natural language environment. As a result of this analysis the authors strongly agree on the benefits of using authentic web resources in teaching English. The analysis has also shown a complete correlation between the use of Internet technologies and course content mastering.
\end{abstract}

KEYWORDS: Educational web resources. Website. Internet technologies. Information search. Language learning. English language.

RESUMO: O artigo discute o uso de recursos educacionais online no processo de aprendizagem da língua inglesa. Os autores apresentam diversos recursos online para o ensino da língua inglesa que se revelam uma fonte eficaz na aquisição de uma segunda língua. Os recursos ajudam a melhorar a percepção da língua estrangeira, estudar regras gramaticais, ensinar a pronúncia correta, a se familiarizar com a cultura da língua-alvo e aumentar o interesse em aprender uma língua estrangeira. A vantagem de usar tais recursos tem por

1 Kazan Federal University (KPFU), Kazan - Russia. Teaching fellow of the Department of Contrastive Linguistics, Institute of Philology and Intercultural Communication. ORCID: https://orcid.org/0000-0003-18003085. Email: nadiya20021@yandex.ru

${ }^{2}$ Kazan Federal University (KPFU), Kazan - Russia. Associate Professor of the Department of Contrastive Linguistics, Institute of Philology and Intercultural Communication. ORCID: https://orcid.org/0000-0003-24131024. Email: zulkin66@mail.ru

${ }^{3}$ Kazan Federal University (KPFU), Kazan - Russia. Associate Professor of the Department of Contrastive Linguistics, Institute of Philology and Intercultural Communication. ORCID: https://orcid.org/0000-0002-16792183. Email: nadiya20021@yandex.ru

${ }^{4}$ American University of Central Asia (AUCA), Bishkek - Kyrgyzstan. Professor and PhD in Uralic and Altaic Studies. ORCID: https://orcid.org/0000-0001-7564-0991.Email: charlescarlson333@gmail.com 
princípio a didática da visibilidade. A representação visual do material prova ser a mais importante e necessária para uma melhor percepção da informação - motivando as crianças a permanecerem focadas na tarefa ao criar um ambiente de linguagem natural. Como resultado desta análise, os autores tiveram uma visão ampla sobre o uso de recursos autênticos da web no ensino da língua inglesa. A análise também mostrou uma correlação completa entre o uso de tecnologias da Internet e o domínio do conteúdo do curso.

PALAVRAS-CHAVE: Recursos educacionais na web. Website. Tecnologias da Internet. Busca de informação. Aprendizagem de línguas. Língua inglesa.

RESUMEN: El artículo analiza el uso de recursos web educativos en el proceso de aprendizaje del idioma inglés. Los autores presentaron diferentes recursos web para la enseñanza del idioma inglés que resultan ser una fuente eficaz en la adquisición de un segundo idioma. Los recursos web ayudan a mejorar la percepción del idioma extranjero, estudian las reglas gramaticales, enseñan la pronunciación correcta, se familiarizan con la cultura del idioma de destino y aumentan el interés en aprender un idioma extranjero. La ventaja de utilizar recursos web radica en el principio didáctico de visibilidad. La representación visual del material demuestra ser la más importante y necesaria para una mejor percepción de la información y, en general, para motivar a los niños a mantenerse enfocados en la tarea creando un entorno de lenguaje natural. Como resultado de este análisis, los autores obtuvieron una impresión completa sobre el uso de recursos web auténticos en la enseñanza del idioma inglés. El análisis también ha mostrado una correlación completa entre el uso de tecnologías de Internet y el dominio del contenido del curso.

PALABRAS CLAVE: Recursos web educativos. Sitio web. Tecnologías de Internet. Búsqueda de información. Aprendizaje de idiomas. Idioma inglés.

\section{Introduction}

Information and communication technology have become an integral part of our everyday lives. Schools should, therefore, respond to the current social requirements and prepare individuals in accordance with the needs of an emerging information society [10, 2]. Today, in the era of informatization, characterized by the intensive use of information technologies in all areas of society, including the educational system, teaching foreign languages without the use of multimedia teaching tools is unimaginable (VASSILIEVA; DRUGOV, 2019, p. 464). For this reason, we can hardly imagine any English language class without using electronic learning resources. The effective use of advanced technologies during learning and self-studying has become widespread in pedagogics. The issue of searching for necessary content takes on a great importance with the development of the Internet and multiplication of its published information resources. Professor Grigoryev S.G. and professor Grishkun V.V. believes that: "for the system of general secondary education it involves 
searching such information resources posted on the Internet that could increase the efficiency of schoolchildren training system in practical terms", (GRIGORYEV; GRISHKUN, 2005, p. $82)$.

\section{Methods}

In the course of our research the following methods were used: analysis of scientific and methodological literature on the research problem, scientific observation, generalization of the study results, synthesis.

\section{Results and discussion}

Informatization of education is to transform pedagogical processes strategies on the basis of implementation of information products into teaching process. Two objectives are achieved simultaneously in this case: implementation of information and telecommunication technologies and improvement of specialists' training quality with new type of thinking which satisfy the requirements of information-oriented society.

According to «The National Curriculum for England» innovation is a unique factor being important for language learning, for implementing into virtual learning conditions which includes all the necessary equipment, place, use of space and learning resources selection for teaching process support and solving learning problems by creating the best conditions for students. Education process is penetrated with information technologies to a great extent. Due to a great number of web resources it is important to bear in mind the fact that in information environment the students have an opportunity to think critically and independently, to find their own ways. It serves as an undeniable advantage of information technologies use. Innovation process in language learning is associated with the transition of education to a qualitatively different state, with a revision of outdated rules and regulations, roles of the teacher and students, and often with their revision (KABIROVA et al., 2018, p. 2469).

The term «web resource» (also «Internet resource», «website», «web service», «site», etc.) is an aggregate of integrated technical, hardware and software resources, and information designed for the Internet online publishing. The Internet resource can contain information in textual, graphical and multimedia form as well. With the arrival, growth, and development of personal desktop computers and later mobile technologies, there has been a significant shift in methods of teaching and learning languages (KOSTYUCHENKO; TRUTNEV, 2018, p. 1). 
Electronic educational resources can be distinguished as a separate branch of web resources and this term combines all the range of learning techniques which are exploited and reproduced on the basis of computer technologies.

So, the use of the Internet and web resources serve many didactic purposes, such as:

1) Web resources simplify information search to a great extent;

2) Information obtained from web sources is always kept up to date due to occurring changes in different facets;

3) The use of authentic web resources boosts pupils' motivation, i.e. serves as an incentive to language learning;

4) Web resources give an opportunity to listen to native speaker scripts which can help improve listening comprehension skills;

5) Web resources give further scope for improvisation, as opposed to traditional methods of teaching children.

Nevertheless, only teacher's creative potential can offer an opportunity for search of interesting and mainly useful informative web resources for learning a foreign language. This also means that a web resource appears to be an addition to the improvement of language level.

It is essential that one should be a child psychology expert for the correct use of web resources. Each age has its leading type of activity. Motives encouraging a pupil to study English can be different but the sooner the child begins studying the language, the easier he or she succeeds in learning it. Thus, the intensive development of listening skills, vocabulary learning, incidental memorization of grammatical forms, the increase in the motivational component of training, i.e. all positive moments, which are observed in the process of training in natural environment, are now achieved in the conditions of its artificial modeling (MUKHAMADIAROVA; MERKISH; KULKOVA, 2018, p. 333).

Preschool and school aged children perceive the English language as something new. The factor of correct psychological and pedagogical approach to language learning acquires great importance. It is considered that the best age to start learning a foreign language is between the ages of about 4 and 7, when the mother-tongue system has already been shaped. The leading type of activity is playing games, because of children's unstable attention and excessive physical activity. This age group is characterized by involuntary memorization, so the children memorize what evokes emotional response in their souls. The game forms of training are more 
effective for preschool and primary school aged children in learning English. This age is also characterized by speech acquisition plasticity which declines over time.

With transition from primary to high school age, the child's position in society changes, he becomes more involved in different activities, has less time for rest and his perseverance increases. Adolescence is characterized by the process of active cognitive development. Game activities are not suitable at this stage, face to face interaction, educational and professional activities are prioritized. There is a gradual transition of leading activity from play to learning.

High school age can be described in terms of the development of main types of activities, such as studying, labor and interaction. They can use notions, ratiocinate some phenomena while they have the base of learning skills developed which is proved useful in the future.

Every school age has its own peculiarities which should be taken into consideration in learning a foreign language. That is the reason why different web resources suggest special sections for children of different ages.

\section{Teaching listening comprehension}

Many search servers suggest the use of some dictionaries with built-in microphone which helps record the speech and then reproduce it, or listen how a certain foreign phrase may sound. Moreover, speech synthesizers are developed which turn the written text into an audio file (A1 SpeechTRON, ReadPlease, ReadingBar, FlameReader, Alive Text to Speech, YeoSoft Text to MP3 Speaker, CoolSpeech). The text should be inserted or copied from any textbook into the window and then it is repeated automatically.

\section{Teaching reading}

The access to computer technologies give an opportunity to use online newspaper and authentic book sources. Almost all world journals and newspapers have their own web pages which help not only to enhance reading skills but also to increase vocabulary. Newspaper as an additional resource in language teaching helps the students keep track of events of a targetlanguage country.

a. The Washington Post ${ }^{5}$

5 Available in: https://www.washingtonpost.com/. Access: 10 dec. 2020. 
The front page presents the current events guide with the most dramatic news to draw the potential readers' attention. The Washington Post in divided into five main sections: news, style, sports, classifieds, marketplace.

\section{b. BBC World Service ${ }^{6}$}

This site allows not only to read the news but also to listen them in different languages. The site also presents a special section for the English language learners named «Learning English». The section includes video clips, reading and listening comprehension texts, exercises for phonetic, lexical and grammar skills development as well as games and quizzes.

\section{c. $\mathrm{ABC} \mathrm{News}^{7}$}

The following web resource presents news which a reader can read and listen, and also video trackers to them. The Chat section offers a discussion on one of the suggested topics.

d. CNN World News ${ }^{8}$

CNN site opens an opportunity to read information in several languages with audio and video trackers as well. The readers and editors' feedback is possible using Discussion section.

e. The New York Times ${ }^{9}$

An American daily newspaper with all above mentioned offers a version with ready lesson plans.

\section{Online dictionaries}

While teaching reading, it is essential to know how to transcribe words and their word stress. Online dictionaries can be rather helpful in this case. They are the following:

- Cambridge Dictionaary ${ }^{10}$

- Oxford dictionary ${ }^{11}$;

- Multitran ${ }^{12}$ and others.

6 Available in: http://www.bbc.co.uk/worldservice. Access: 10 dec. 2020.

7 Available in: https://abcnews.go.com. Access: 10 dec. 2020.

8 Available in: http://cnn.com/WORLD. Access: 10 dec. 2020.

9 Available in: https://www.nytimes.com/. Access: 10 dec. 2020.

10 Available in: https://dictionary.cambridge.org/ru/. Access: 10 dec. 2020.

11 Available in: https://www.oxfordlearnersdictionaries.com/. Access: 10 dec. 2020.

12 Available in: https://www.multitran.com/. Access: 10 dec. 2020. 


\section{Teaching speaking}

Learning language, improving grammar and gathering vocabulary size, one should not forget about speech practice. As a rule, in Russian schools English is not taught by native speakers, so if a child needs to develop speaking skills, he can visit web sites where he can practice his speech, such as, LinguaLeo, Italki and others.

As Potapova R.K notes, in spite of adding entertaining elements to the lesson, Internet technologies will not be successful without the teacher's inclusive approach, but they facilitate a solution all types of speech activity (POTAPOVA, 2005, p. 368).

\section{Summary}

On the basis of what has been stated above, educational web resources assist the teacher in developing productive learning skills, expanding the lesson and making it creative and not stereotyped. The Internet resources potential for language learning is enormous and it enables acquisition of any information from anywhere in the world. Moreover, web resource information is constantly updating due to innovations in language learning. Regular use of these resources at second language lessons increases children's cognitive activity and stimulates further language learning respectively.

\section{Conclusions}

The main advantage of web resources of the English language learning is an access to authentic materials and an opportunity to practice casual speech with native speakers. Educational web resources provide the students with additional learning content and gives space for self-education. Special websites are created to promote the teaching of listening comprehension, reading, speaking and which are represented by web-based language applications, online authentic newspaper issues, online dictionaries and others. Web resources significantly simplify information search for both teachers and students.

ACKNOWLEDGEMENTS: The work is performed according to the Russian Government Program of Competitive Growth of Kazan Federal University. 


\section{REFERENCES}

GRIGORYEV, S. G.; GRISHKUN, V. V. Informatization of education. Fundamental basics. Moscow, 2005. 227 p.

KABIROVA, A. A. et al. Educational Internet Resources in Turkic Languages. HELIX, v. 8, n. 1, p. 2469-2472, 2018.

KAYUMOVA, A.; SADYKOVA, G. Implementing a multimodal online program for very young learners of Russian: Educators' perspective. Indonesian Journal of Applied Linguistics, v. 9, n. 1, p. 1-13, 2018.

KOSTYUCHENKO, M. V.; TRUTNEV, A. Y. Internet resources in the English language learning. International Journal of applied and fundamental research, n. 1, p. 181-185, 2018.

MUKHAMADIAROVA, A. F.; MERKISH, N. E.; KULKOVA, M. A. The advantages of using multimedia cultural and linguistic environment in the process of teaching foreign languages. Revista Publicando, v. 5, n. 16, p. 332-339, 2018.

N VASSILIEVA, V.; V DRUGOV, A. Integrative Use of "Techno-R" Remedial Technology and Gaming Technology in Teaching Foreign Language Listening. In: INTERNATIONAL CONFERENCE ON APPLIED LINGUISTICS ISSUES, 6., 2019, Saint Petersburg.

Proceedings [...]. Saint Petersburg, Russia, 2019. p. 463-472.

POTAPOVA, R. K. New information technologies and linguistics: teaching guide.

Moscow: KomKniga, 2005. 368 p.

UHLIROVA, M. Semantic space of elementary teacher attitudes towards computer teaching assistant. Global Journal of Information Technology: Emerging Technologies, v. 8, n. 1, p. 1-9, 2018.

\section{How to reference this article}

DANDAN, S.; FAZLYEVA, Z. K.; SAMARKINA, N. O.; CARLSON, C. Educational web resources as an essential part of the english language learning process. Rev. EntreLínguas, Araraquara, v. 7, n. esp. 1, p. 39-46, fev. 2021. e-ISSN: 2447-3529. DOI: https://doi.org/10.29051/el.v7iEsp1.14859

Submitted: $28 / 10 / 2020$

Required revisions: $19 / 12 / 2020$

Approved: $13 / 01 / 2021$

Published: 28/02/2021 